\title{
ANALYSIS OF POSSIBILITIES AND PROPOSALS OF INTELLIGENT TRANSPORT SYSTEM (ITS) IMPLEMENTATION IN LITHUANIA
}

\author{
Aldona Jarašūnienè \\ Transport Research Institute, Vilnius Gediminas Technical University, \\ Plytinès g. 27, LT-10105 Vilnius, Lithuania. \\ E-mail: ajarasuniene@yahoo.com
}

Received 22 May 2006; accepted 4 September 2006

\begin{abstract}
ITS covers all modes of and considers all elements of the transportation system - the vehicle, the infrastructure, and the driver or user, interacting together dynamically.

Information is at the core of ITS whether it is static or real-time traffic data or a digital map. Many ITS tools are based on the collection, processing, integration and supply of information. Data generated by ITS may provide real-time information about current conditions on a network, or on-line information for journey planning, enabling highway authorities and agencies, road operators, public and commercial transport providers and individual travellers to make better informed, safer, more coordinated and more 'intelligent' decisions or 'smarter' use of networks.

There are studies showing estimation of ITS implementation in foreign countries and in Lithuania, ITS vision, the conclusions of SWOT analysis, possible technical solutions of ITS deployment, ITS planning and financing and measures of ITS deployment in Lithuania.
\end{abstract}

Keywords: proposals and possibilities of ITS, traveller and traffic information, ITS subsystems, ITS planning.

\section{ITS application areas and uses}

\subsection{Improving Safety and Security}

ITS services can make transport safer and more secure. They can maximise its capability to contain and reduce the impact of disasters, natural and manmade, e.g. by forward planning, cutting emergency service response times, and securing and prioritising disaster evacuation routes. They can deliver sustained reductions in both the numbers and severity of accidents, by alerting travellers to dangerous conditions and situations, and, if necessary, intervening in the driving task. They can enforce safety regulations, deter dangerous driving, monitor hazardous loads and screen suspect vehicles and con-tainers. They can protect vulnerable road users by making them more visible to drivers, by giving pedestrians and cyclists control over their use of crossings, or by automatically reducing the speed of approaching vehicles or helping the driver with visual aids or alerts [1-5].

Relevant ITS services include:

- Intelligent speed adaptation;

- Assistance for vulnerable road users;

- Weather and road condition monitoring and information;
- Incident detection and warning systems;

- Collision warning systems;

- Emergency vehicle priority;

- Driver monitoring systems;

- Speed and traffic signal enforcement;

- Hazardous load monitoring;

- Cargo screening;

- Driver vision enhancement systems;

- Evacuation route signing and priority;

- Homeland security initiatives;

- People with a disability will benefit from better visual and audio presentation of information.

\subsection{Helping to relieve congestion}

Congestion is a major problem for all transport networks, and increasing the efficiency of existing transport systems is a major goal of ITS programs around the world. Congestion can be reduced by instrumenting networks to improve their real-time operation; introducing control systems; managing demand; and encouraging off-peak travel or the use of alternative modes. Relevant ITS services include network efficiency, demand management, encouragement of modal shift. 


\subsection{Environmental monitoring and protection}

Public concerns about the environmental impact of our transport systems have intensified in recent years. Worldwide, the use of motor vehicles still shows no sign of decreasing and road traffic continues to rise. As a result, the environmental impacts from emissions and noise have become increasingly serious. Clearly urgent actions are needed from the transport sector toward environmental improvement, especially a reduction in carbon dioxide $\left(\mathrm{CO}_{2}\right)$ and nitrogen oxides $\left(\mathrm{NO}_{\mathrm{X}}\right)$ emissions and in the management of urban and inter-urban traffic.

Making transport systems run more efficiently can also bring corresponding benefits for the environment. ITS have much to offer here. For example, reducing traffic congestion or encouraging more people to travel by public transport directly reduces vehicle emissions and consequently air pollution. Environmental monitoring and evaluation of various environmental parameters are becoming especially important, in order to quantify the effects of polices and programmes.

Most of the services listed in the previous section are relevant for tackling environmental problems. Among specific applications, access control can protect particularly sensitive and vulnerable areas; while flexible Electronic Fee Collection (EFC) can charge drivers more for driving at times of high pollution risk. Distance-based lorry road user charging makes it possible to charge the most directly damaging vehicles for their use of the infrastructure.

\subsection{Productivity and operational efficiency}

ITS can make transport operations more efficient. Fleet management systems can reduce administrative and operational costs and deliver substantial improvements in productivity, e.g. by enabling reliable journey time calculations and just-in-time delivery; and using positioning and communications technologies to enable the most effective deployment of drivers and vehicles. Electronic pre-clearance (including across borders), compliance checks and weigh-inmotion are major time savers. Wider benefits include more rational use of the highway infrastructure, reduced congestion and pollution, and less risk of accidents due to monitoring vehicle and driver condition. Relevant ITS services include:

- Fleet management;

- Computer-aided dispatch (CAD);

- Automatic vehicle location (AVL);

- Automatic cargo tracking;

- Electronic pre-clearance;

- Vehicle compliance checking;

- Driver monitoring.

\subsection{Comfort factors}

Users of any transportation system need to feel comfortable, confident and secure. Route confirmation, journey time estimates and clear advice on approaching interchanges and connections all play their part. Speed controls, ramp metering, advance incident and congestion warnings, and alternative route guidance can make road journeys easier and less stressful. Facilities such as multimedia systems that provide both entertainment and navigation can do this too. Public transport users also expect high standards of comfort, convenience and service. ITS can provide the real-time passenger information, automated scheduling and priority systems needed to improve public transport. Relevant ITS services include:

- Real-time traffic and public transport information;

- Dynamic route guidance;

- Automatic vehicle location (AVL);

- Smartcard payment systems for toll highway and public transport use.

\section{Estimation of ITS implementation in foreign countries and in Lithuania}

Estimation of ITS implementation situation in foreign countries and in Lithuania is shown in Table 1 .

\section{ITS vision}

ITS vision is: to consider certain aspects of ITS services, to make a strategic development plan and ITS architecture mostly adequate to the demands of clients. ITS deployment is a new input to the partnership rela-tions between different interests of various transport mo-des, between different administrative levels and business environment and population sectors [8]. Development of ITS market depends very much on partnership relations.

ITS in Lithuania does not mean a separate Lithuanian system. It is a process of implementation of the achievements of logistics and telematics. ITS vision consists in the timely delivery of available range of services to the clients' business. At the same time ITS services should guarantee the best terms of cost.

ITS vision includes:

- Creating an active safety system in road transport;

- Creating the national road database (network, pervasion of vehicles, etc.); 
Table 1. Estimation of ITS situation in foreign countries and in Lithuania

\begin{tabular}{|c|c|c|c|c|}
\hline Countries & Problems & Solution problems by ITS & \begin{tabular}{|c|} 
ITS programs \\
\end{tabular} & \begin{tabular}{|c|} 
Perspectives \\
\end{tabular} \\
\hline Belgium & $\begin{array}{l}\text { 1. Traffic congestion } \\
\text { 2. Road congestion } \\
\text { 3. Explosive growth of } \\
\text { freight transport } \\
\text { 4. A large number of peo- } \\
\text { ple commute to work by } \\
\text { car }\end{array}$ & $\begin{array}{l}\text { 1. Separate federal states } \\
\text { have their own policy } \\
\text { for traffic manage- } \\
\text { ment and use of ITS } \\
\text { 2. } \text { Mobility management } \\
\text { centre } \\
\text { 3. Detection in display of } \\
\text { travel time } \\
\text { 4. Information by e-mail, } \\
\text { radio, system in car } \\
\text { 5. Red light and speed } \\
\text { cameras are used more } \\
\text { on motorways and ma- } \\
\text { jor roads }\end{array}$ & $\begin{array}{l}\text { 1. Take part in all com- } \\
\text { mon EU program by } \\
\text { ITS }\end{array}$ & $\begin{array}{l}\text { 1. Future new road infra- } \\
\text { structure projects } \\
\text { likely to have toll col- } \\
\text { lection } \\
\text { 2. Ready to deploy a } \\
\text { web-based platform } \\
\text { for essential pre-trip } \\
\text { information which will } \\
\text { host a multi-modal trip } \\
\text { planner } \\
\text { 3. ITS projects }\end{array}$ \\
\hline $\begin{array}{l}\text { Czech } \\
\text { Republic }\end{array}$ & $\begin{array}{l}\text { 1. Levels of car ownership } \\
\text { and traffic con-gestion } \\
\text { have exceed-ed all car- } \\
\text { rier forecasts } \\
\text { 2. Growth of accidents on } \\
\text { roads } \\
\text { 3. Traffic control centres } \\
\text { are in bigger cities only } \\
\text { 4. Traffic data and infor- } \\
\text { mation distribution is } \\
\text { not yet used for urban } \\
\text { transport management }\end{array}$ & $\begin{array}{l}\text { 1. The association for } \\
\text { Transport Telematics } \\
\text { of the Czech Republic } \\
\text { was established in } 2000 \\
\text { 2. Warning systems using } \\
\text { speed detectors, fire } \\
\text { optic signs and flashing } \\
\text { lights }\end{array}$ & $\begin{array}{l}\text { 1. Take part in national } \\
\text { and international ITS } \\
\text { programs }\end{array}$ & $\begin{array}{l}\text { 1. There is a need to } \\
\text { improve the coordina- } \\
\text { tion of telematics with } \\
\text { other transitional cou- } \\
\text { ntries in Eastern Euro- } \\
\text { pe in view of the stra- } \\
\text { tegic position of the } \\
\text { Czech Republic in re- } \\
\text { lation to CE and the } \\
\text { EU } \\
\text { 2. Improvement of traf- } \\
\text { fic safety } \\
\text { 3. ITS projects }\end{array}$ \\
\hline Germany & \begin{tabular}{|l} 
1. Most transport is by \\
road which carry $80 \%$ \\
of passenger transport \\
and $70 \%$ of goods \\
transport \\
2. Accidents on the roads \\
3. New ITS services focus \\
on individual in- \\
formation and appear as \\
add-ons to the conven- \\
tional system
\end{tabular} & $\begin{array}{l}\text { 1. The Federal Minister } \\
\text { of Transport chairs the } \\
\text { Economic Forum for } \\
\text { Transport Telematics, } \\
\text { a public/ private part- } \\
\text { nership aiming at pro- } \\
\text { moting development } \\
\text { and implementation of } \\
\text { ITS systems and ser- } \\
\text { vices } \\
\text { 2. Traffic information is } \\
\text { collected from various } \\
\text { traffic control systems } \\
\text { 3. Dynamic parking guid- } \\
\text { ance systems in most } \\
\text { bigger cities } \\
\text { 4. Variable message sign } \\
\text { systems } \\
\text { 5. Regional public and } \\
\text { private radio stations } \\
\text { provide information }\end{array}$ & $\begin{array}{l}\text { 1. The large European } \\
\text { ITS research and de- } \\
\text { velopment program- } \\
\text { mes and implementa- } \\
\text { tion of field test ways } \\
\text { of approaching a } \\
\text { large-scale national } \\
\text { implementation stra- } \\
\text { tegy }\end{array}$ & 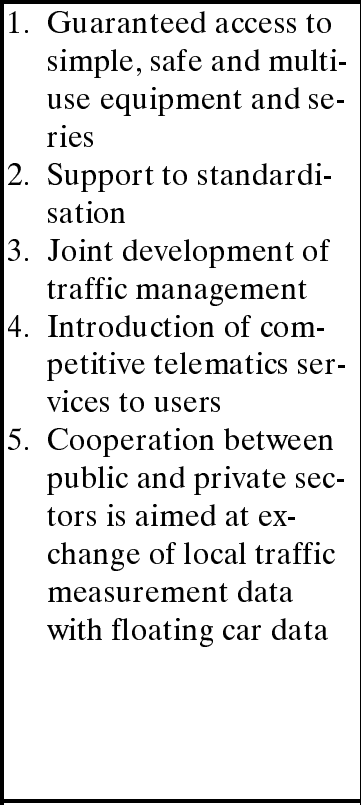 \\
\hline Lithuania & $\begin{array}{l}\text { 1. Traffic congestion } \\
\text { 2. Road congestion } \\
\text { 3. Accidents on roads } \\
\text { 4. There is no free of } \\
\text { charge connecting dur- } \\
\text { ing travel time } \\
\text { 5. There are no data base } \\
\text { of hazardous transporta- } \\
\text { tion by road transport } \\
\text { 6. There is no juridical and } \\
\text { organizational fundation } \\
\text { to ITS development }\end{array}$ & $\begin{array}{l}\text { 1. There is episodic road } \\
\text { weather condition in- } \\
\text { formational system } \\
\text { 2. Digital tachografs } \\
\text { system } \\
\text { 3. Episodic speed detec- } \\
\text { tive maintenances }\end{array}$ & \begin{tabular}{|l|} 
1. Insufficient level of \\
scientific technological \\
development and in- \\
novation implementa- \\
tion in ITS field
\end{tabular} & $\begin{array}{l}\text { 1. Implementing of } \\
\text { automatical and regu- } \\
\text { lational traffic-light } \\
\text { system }\end{array}$ \\
\hline
\end{tabular}


- Creating the data accumulation system and transport database;

- Databases related to transportation of dangerous goods by road vehicles;

- Possibility of free use of information during the travel time;

- Reduction of congestion in public transport.

Positive and negative factors. Processes of creating of national ITS architecture, as well as introduction of ITS in transport, encounter various kinds of problems that have to be solved. Such problems are:

- Considerably low level of technical and organisational knowledge in this field;

- Low-level political and public awareness and support;

- Uncertain financing from public and private sources;

- Difficulties of interinstitutional cooperation.

Positive factors - urban and regional communities and society are more and more aware of the advantages given by application of solutions of Intelligent Transport Systems in terms of efficiency, safety and environment safety. However it is important to have in mind that ITS alone are not able to solve urban transport problems in full. They can create valuable packages of instruments enabling a significant reduction of such problems. It should be noted that for further general development it is extremely important to have truthful information on ITS advantages that are inducing progress and on the actions that should be undertaken for ITS deployment, and on the organisation methods of their wide propagation.

Existing practical examples of foreign experience should be used in the planning and dissemination of ITS development strategy. This should be applied in the fields with the largest local and regional demand, such as:

- Management of traffic data and its accumulation technologies;

- Urban traffic control;

- Public transport control and scheduling;

- Real-time information in public transport.

\section{The overall conclusions of SWOT analysis of ITS deployment in Lithuania}

The SWOT analysis of ITS deployment in Lithuania enables us to make the following conclusions:

1. Implementation of opportunities by making use of advantages is possible due to:

- Awareness of businessmen about the importance of speeding up the production of information technologies and delivery of services:

- Favourable attitude of the Parliament and governmental institutions towards the information society and ITS development;

- Sufficiently dense network of transport and communications.

2. To use the opportunities for elimination of disadvantages is possible by:

- Creating the database of traffic accidents;

- Traffic management and control modernisation with the involvement of ITS, thus ensuring traffic safety and increasing road throughput capacity;

- Supporting the scientific research programmes and using the opportunities of ITS deployment by close cooperation with stakeholders;

- Using EU financial support for modernisation of road transport sector with the aim of solving traffic safety problem on the EU scale.

3. Threats would decrease with:

- Creation of an active road transport traffic safety system;

- Reduction of congestion in public transport;

- Enhancement of scientific research, technological development and innovations in the field of ITS.

4. Risk factors, if ITS deployment fails in the nearest future:

- Lithuania's road safety improvement obligations in the context of EU membership will not be carried out;

- Lithuanian roads will not meet technical and quality requirements of Trans-European road transport network;

- The opportunity can be lost for using EU funds specially designated for the development of information technologies and telecommunications and for the integration of these measures into the ITS development;

- Lithuania may remain among the backward countries and may lag behind due to the more rapid development of ITS in foreign countries.

\section{Possible technical solutions of ITS deployment}

Firstly, with the aim of integration of Lithuanian ITS into the EU system of ITS it is necessary to orient to the KAREN project [1-7], which is a project for elaboration of ITS architecture guidelines for deployment of active and operating ITS in the EU by 2010 and later.

In the process of creating the ITS architecture for public organisations and business stakeholders it is necessary to decide upon the form of the architecture which should be created. Such form may be one of the following three types:

- Structure architecture, i.e. the architecture consisting of consumer demands and functional aspect. It may be used in the process of creating the architectures of the following two types and 
it is the only type of architecture really applicable for national level architectures.

- Legacy architecture having physical, communication and other aspects plus capacities. It may be used on the national, regional and local levels with concretisation of ITS deployment needs. The content of physical aspect can be fixed or limited [9-10].

- Service architecture, which is like the legacy architecture, however it only supports/maintains the exclusive service, as for example management of road accidents, travel information, public transport management, etc.

ITS architecture has to be developed with the aim of coordination of all ITS components into one framework structure, so that their interoperability could be reached in the delivery of necessary services to customers.

Specific architecture can be expressed by multiple forms. It is necessary that stakeholders should understand and approve the concepts and functions that inform the development of ITS operations and institutional architectures. On their part, ITS designers have to work with logical, physical and telecommunication architecture that will present operational and functional requirements.

Lithuanian ITS architecture should be sufficiently enough adjusted to defined local requirements. This will be expressed with the view to the functional requirements, logistical architecture and organisational architecture.

Each aspect of architecture is related to ITS implementation plans and can precisely indicate where it will be important to ensure interinstitutional agreements of common operation, or to define the value of common regional standards used. Properly carried out and well explained to society the ITS architecture analysis will demonstrate the whole range of interrelations necessary for operators in different institutions with the aim of efficient delivery of ITS services. Examples:

- Interoperability of intended new or of modernised existing ITS traffic regulation systems and travel information services;

- Stock of available and necessary for the region data transmission and telecommunication systems;

- Opportunities rendered by new and modernised data accumulation and traffic management methods with the aim of delivering real-time information.

ITS architecture can not be created in the abstract. It is necessary to regard national peculiarities and especially local situations, for instance, when certain stakeholders may have had already significant investments to legacy systems. It may become the main ITS architecture analysis factor influencing the regional architecture in two ways - both as an opportunity and as a restriction. Experts should pay their particular attention to the necessity of seeking the operation of certain systems coordinated on the national level [11-12].

\section{ITS planning and financing}

In accordance with the experience of foreign countries, the process of creating the Lithuanian strategic planning with regard to all ITS implementation actors is presented in Table 2 .

Whereas the ITS environment is complex and multi-lateral, the problem of their creating should be considered on all levels of the State, i.e. by the Seimas of the Republic of Lithuania, by the Government, by the municipalities, by stakeholders, and by all traffic actors. Thus the close cooperation of all these institutions will be ensured.

Scheme of long-range implemented model of ITS in Lithuania is shown in Figure.

\section{Measures of ITS deployment}

Existing situation:

1. Real-time travel information is not delivered.

2. Transport flows on Lithuanian main roads and urban streets are constantly growing, congestion becoming a threat to traffic safety.

3. Traffic management and travel safety do not meet the growing demands of traffic actors, ITS services are not delivered to travellers.

4. ITS initiatives are faint in Lithuania; also there is insufficient support on the governmental scale.

5. Due to the lack of good quality road transport information infrastructure, and as a maritime country through which two main international transport corridors of European importance are going, Lithuania does not exploit all available transit and tourism potentials.

6. Measures of road information infrastructure impro-vement in Lithuania are insufficiently applied, and their efficiency in road safety is poor.

Objectives: creating of modern road transport information infrastructure by technical parameters and by service quality corresponding to the standards of EU Member States, and accordingly integrated into the EU transport information infrastructure enabling good road safety on Lithuanian roads.

\section{Tasks:}

- Improvement of road information infrastructure.

- Improvement of traffic conditions on roads and streets.

- Enhancement of traffic safety.

- Creating of accident management system. Table 3 shows ITS services (according to ISO/TR 14813-1:1999) for the period in Lithuania. 
Table 2. Summing-up of ITS strategic planning in Lithuania

\begin{tabular}{|c|l|l|}
\hline Step & \multicolumn{1}{|c|}{ Actions } & \multicolumn{1}{|c|}{ Existing situation in Lithuania } \\
\hline Step 1 & $\begin{array}{l}\text { Defining the regional demands for trans- } \\
\text { portation }\end{array}$ & Tables and forecasts made on the basis of statistical data \\
\hline Step 2 & Inventory of existing ITS & Meteorological/Weather forecast system \\
\hline Step 3 & Review of main stakeholders plans & No existing plans yet \\
\hline Step 4 & Valid agreements between stakeholders & $\begin{array}{l}\text { Agreements do not exist yet. Ways should be sought in this direc- } \\
\text { tion }\end{array}$ \\
\hline Step 5 & Analysis of roles and obligations & $\begin{array}{l}\text { Agreements should be elaborated with explication of roles and } \\
\text { obligations }\end{array}$ \\
\hline Step 6 & Documentation & $\begin{array}{l}\text { Preparing a number of documents defining proposals and rea- } \\
\text { soning the agreements of all stakeholders }\end{array}$ \\
\hline
\end{tabular}

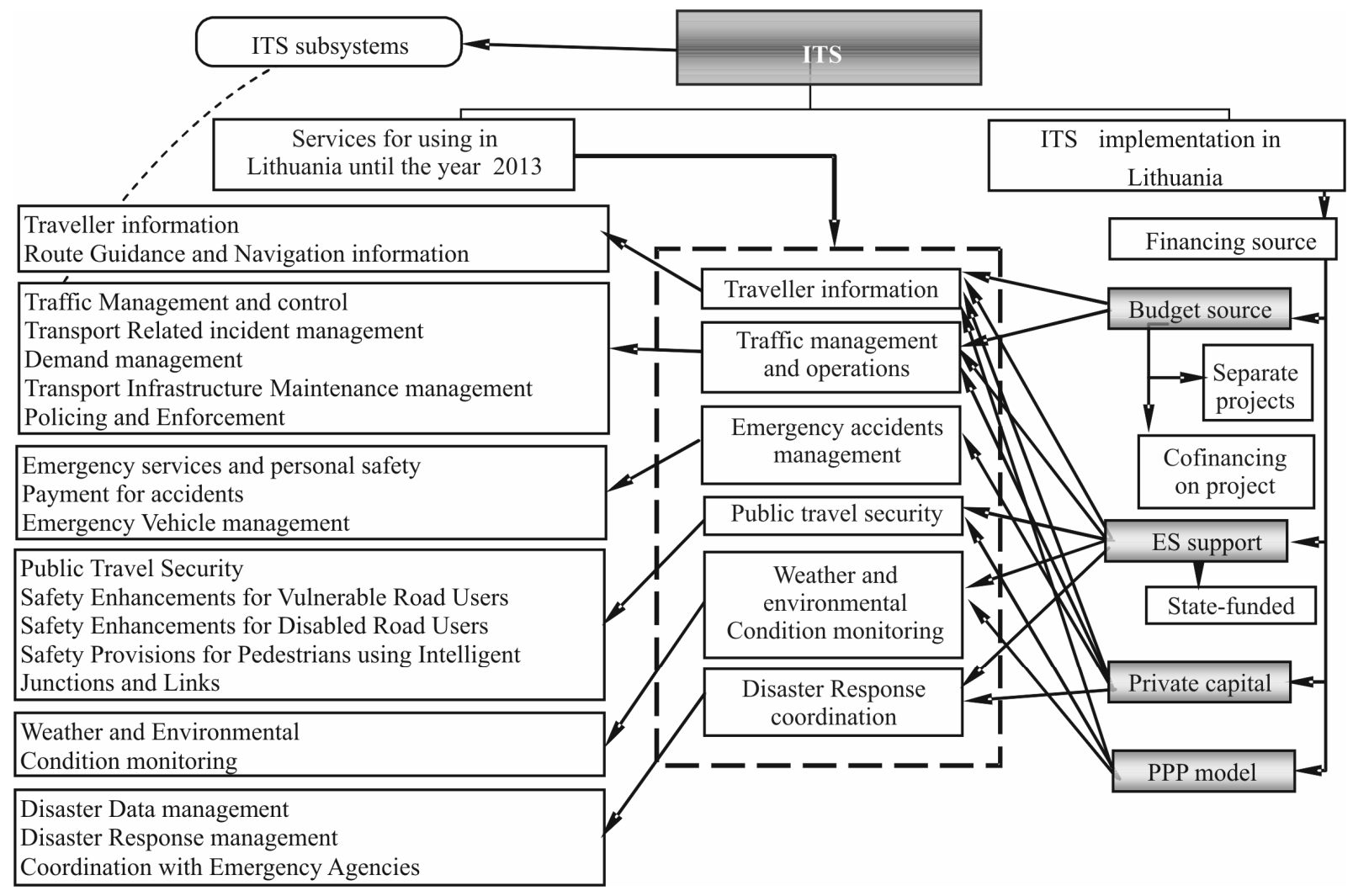

Scheme of long-range implemented model of ITS in Lithuania

Table 3. ITS services (according to standard ISO/TR 14813-1:1999) in Lithuania

\begin{tabular}{|l|c|l|}
\hline \multicolumn{1}{|c|}{ Services Category } & $\begin{array}{c}\text { Service } \\
\text { Number }\end{array}$ & \multicolumn{1}{|c|}{ Service name } \\
\hline Traveller information & 1.1 & Traveller information \\
& 1.2 & Traffic information \\
\hline \multirow{3}{*}{ Traffic management and } & 2.1 & Traffic management and control \\
operation & 2.2 & Transport Related Incident management \\
& 2.3 & Demand management \\
& 2.4 & Transport Infrastructure maintenance management \\
Emergency accidents & 2.5 & Policing traffic regulation \\
management & 3.1 & Emergency services and personal safety \\
& 3.2 & Payment for accidents \\
& 3.3 & Emergency vehicle management \\
Public travel security & 3.4 & Hazardous material and Incident notification \\
& 4.1 & Public Travel security \\
& 4.2 & Safety Enhancements for Vulnerable Road users \\
& 4.3 & Safety Enhancements for Disabled Road users \\
& 4.4 & Safety Provisions for Pedestrians using Intelligent Junctions and \\
\hline
\end{tabular}




\begin{tabular}{|l|c|l|}
\hline \multicolumn{1}{|c|}{ Services Category } & $\begin{array}{c}\text { Service } \\
\text { Number }\end{array}$ & \multicolumn{1}{c|}{ Service name } \\
\hline Weather and Environmental & 5.1 & Weather monitoring \\
conditions monitoring & 5.2 & Environmental conditions monitoring \\
\hline \multirow{3}{*}{ Disaster Response coordination } & 6.1 & Disaster Data management \\
& 6.2 & Disaster Response management \\
\hline
\end{tabular}

\section{Conclusions}

Therefore it is necessary to:

- Consider ITS problems as social problems, with emphasis on the fact that by the absence of ITS people will suffer significant losses in terms of time, health, mobility, etc.

- Create a vision of ITS development acceptable to the public society.

- Integrate different transport programmes linking them by general principles: accessibility, mobility, traffic safety and environment safety.

- Prepare a Governmental long-term ITS development transition programme together with respective regional, local programmes.

- Define a clear and precise competence and responsibility framework of institutions operating in the field of ITS development, and to foresee their coordination actions on the governmental, regional and local levels.

- Establish the Transport Telematics Association of the Republic of Lithuania in accordance with the experience of EU Member States (German example: Transport Telematics Economy Forum steered by the Federal Ministry of Transport).

- Crucial institutional ITS issues consist in the following: planning of the deployment; working with the private sector; financing and procurement. ITS related experts of transport have to be acquainted with alternative and advanced methods of solving these institutional issues.

- Experts intending to invest into ITS are advised to thoroughly consider the planning process by discussing it with the main stakeholders. Therefore it is important to have a well-analysed and soundly made ITS Structural plan, which may influence the preparation of ITS implementation plan that will be followed by the creation of a detailed programme of the plan.

- Interinstitutional agreements present an important means for integrated operation of ITS. When the partnership is formed between multiple institutions, particularly if some of them are in private sector, each partner's role and gainings should be absolutely clear to all parties, and better should be protocoled by the Memorandum of Understanding at the earliest possibility.

- With the aim of efficient implementation of ITS the public sector should consider opportunities of close cooperation with the private sector agencies, thus making full use of depositing into ITS, which can be contributed by each of sectors.

- Regarding the ITS business and system characteristics transport enterprises should be open for novelties, for new public procurement forms and for financing agreements.

- For better public awareness, for clearer explanation of ITS to citizens and businessmen and public servants on all levels, it is necessary to provide an urgent issuing of popular, easily accessible publication about the ITS and their possibilities. For the development of ITS in Lithuania no additional legal acts are required. It is just necessary to follow the existing EU legal acts, as the development of ITS in Lithuania should be at once considered from the point of view of integration into the EU TEN-T corridors that are going through the Lithuanian territory.

\section{References}

1. Miles, J.; Chen, K. The intelligent transport System Handbook. PIARC, 2004. 387 p.

2. Converge. Guidelines for the development and assessment of ITS architectures. TR 1101 (Jesty P. H.; Gaillet J. F.; Franko G.). European Commission DG XIII, Brussels, 2004.

3. Jetsy, P. H. and Bossau, R. A. P. Involving stakeholders in ITS architecture creation. ITS word Congres, Madrid, 2003.

4. Sage, A. P. System engineering. J. Wiley Sons, New York, 1992.

5. OSI is Open System Integration, a 7-layer model development for digital communication in the early 1980s by several standards organisations, including the International Standards Organisation (ISO).

6. Intelligent transportation system in work zones. A case study. USA. 2004. 44 p.

7. Shery, L. Report on non-traditional traffic ceuting methods. Tongue Verde Loop Rd. Tucson, AZ 85748, 2003. 505 p.

8. Jarašūnienè, A. Research into freight transport queuing at customs control posts. Transport, 2005, Vol XX, No 4, p. 164-170.

9. www.its-standarts.net/documents

10. www.sac.org/technicalcommunicates/gits.htm

11. Mc Queen, B. and Mc Queen, J. Intelligent transport systems architectures. Artech House. Boston, 2004.

12. Sage, A. P. Systems engineering. J. Wiley Sons, New York, 2003. 